\title{
CLIMATE AND HEALTH IN THE ROYAL NAVY
}

\author{
BY \\ F. E. SMITH \\ From the Medical Research Council Environmental Hygiene Research Unit, London School of Hygiene and \\ Tropical Medicine, Keppel Street, London
}

(RECEIVED FOR PUBLICATION JULY 2, 1957)

In July, 1945, a new form of monthly sickness return was introduced in the Royal Navy. The return called for counts of those men who were on the sick list, i.e., incapacitated by sickness, and of those on the attending list, i.e., with minor ailments who only attended the sick bay for treatment. It was expected that the attending list figures might be more closely related to living conditions than those for more serious illness necessitating absence from duty.

The first review of these returns (Roberts, 1948), covering the period August, 1945, to July, 1946, showed clearly the value of the attending list figures, and the sickness return was amended to require the inclusion of a record of the air temperature on the upper deck at noon.

The next examination, covering the period from October, 1948, to September, 1949 (Ellis, Smith, and Underwood, 1952), showed the value of the records of air temperature. When the returns from all stations were grouped together it appeared that the percentage of a ship's company on the attending list increased as the weather became hotter, and especially when the upper deck temperature exceeded $80^{\circ} \mathrm{F}$. It was not clear whether variations in the numbers on the attending list were in some measure due to factors other than climate, such as station, or class of ship, so it was decided to make a further examination when more returns had been amassed.

In the present study, which covers the four years between October, 1948, and September, 1952, an examination has been made of the question whether the relation between minor sickness and climatic temperature is to be found in all classes of ship and on all foreign stations.

\section{The Sickness Returns}

About $12 \%$ of all the monthly sickness returns received contained obvious errors or could not be readily classified, and these were discarded. The remaining 1,855 were classified in respect to station thus:-
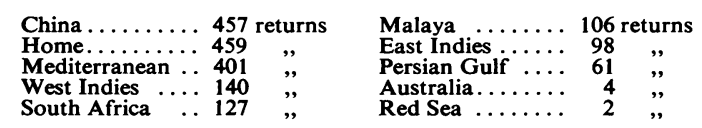

Air temperature measurements were given in 1,806 returns. Of these, 1,608 could be assigned to a particular station, the remaining 198 having been recorded while the ships were passing from one station to another. The number of returns received from maintenance and depot ships was 191 and in some instances, particularly where the effect of climate is considered, these have been excluded when the results have been grouped.

The returns were received from 104 different ships made up of four battleships, 12 carriers, 25 cruisers, 24 destroyers, 27 frigates and sloops, three minesweepers, four maintenance and repair ships, and five depot ships. For some purposes it was desirable to classify the ships in groups thus:-

1. Large ships (battleships, carriers, cruisers)

2. Small ships (destroyers, frigates and sloops, and minesweepers)

3. Maintenance and repair ships and depot ships

Of the 1,855 returns, $39 \cdot 6 \%$ were from large ships, $49.4 \%$ from small ships, and the remaining $11 \%$ were from maintenance and depot ships.

The numbers on the sick list and on the attending list were subdivided according to the cause of sickness thus:-
(a) Skin diseases
(b) Injuries
(c) Upper respiratory infections
(d) Dysenteries and diarrhoeas
(e) All other diseases

The number of men on the attending list is expressed throughout as a percentage of the ship's company. The average value for each monthly return thus represents the average percentage of the ship's 
company on the attending list for that particular month and is based on counts made at midnight every Wednesday. The complement was recorded at the beginning and end of the month and the average complement was taken as the mean of these two values.

The air temperature at noon was measured daily on the upper deck of the ship and recorded each week on the sickness return as the mean of seven observations. The monthly average temperature used in this report is the mean of these four or five weekly averages.

\section{Results}

Average Percentage of a Ship's Company on Attending and Sick Lists.-The average values for the percentage of a ship's company on the attending list and on the sick list for all ships on all stations for the four years under consideration were for the attending list $4.26 \%$ and for the sick list $0.54 \%$.

The average percentage values of the various disease groups were:-

\begin{tabular}{l|c|c|c|c|c}
\hline & $\begin{array}{c}\text { Skin } \\
\text { Disease }\end{array}$ & Injuries & $\begin{array}{c}\text { Upper } \\
\text { Respiratory } \\
\text { Diseases }\end{array}$ & Dysenteries & $\begin{array}{c}\text { All } \\
\text { Other } \\
\text { Diseases }\end{array}$ \\
\hline Attending list $\ldots$ & $\mathbf{1 . 5 3}$ & $\begin{array}{c}\mathbf{0 . 7 6} \\
\text { Sick list } \ldots\end{array}$ & $\begin{array}{c}0.54 \\
0.08\end{array}$ & $\begin{array}{c}0.14 \\
0.10\end{array}$ & $\begin{array}{c}1.29 \\
0.16\end{array}$ \\
\hline
\end{tabular}

The yearly averages were affected by the disposition of the various classes of ship throughout the world, but the variations from year to year were very small.

Effect of Climatic Temperature on Minor Sickness.-The number of men on the sick list is small compared with the number on the attending list, and only the figures for the attending list have therefore been used in examining the effects of climatic temperature on sickness. Skin disease was the group most affected by climatic temperature, and since accidents might well be likewise affected, these two groups have been considered in detail.

On some stations there were only smaller ships, and some classes of larger ships served on only one or two of the stations. Hence the comparison of the incidences of sickness in the separate classes of ship on the different stations is necessarily restricted.

Skin Disease.-The returns for the different classes of ship on the various stations showed that in small ships in the Mediterranean the incidence of skin disease indicated no clear trend with changing temperature, while in maintenance and repair ships on the Home Station there was some decline in that incidence during warm weather. In almost every other instance, whatever the station or the class of ship, there was an increase in skin disease as the weather became hot. Hence, in order to ascertain at what climatic temperature the increase in skin disease becomes significant some grouping of data is desirable. The incidence of sickness in maintenance and depot ships is not strictly comparable with that seen in the other classes, and they have therefore been omitted from the grouping.

The returns from all other ships when grouped for each station separately showed a rise in the incidence of skin disease with increase of climatic temperature. At temperatures above $75^{\circ} \mathrm{F}$. the incidence of skin disease was much higher in the Persian Gulf than on any other station, while on the South Africa station the incidence of skin disease was generally somewhat higher than on the remaining stations other than the Persian Gulf. However, only 28 returns were received from the Persian Gulf, so that when the figures for all stations are combined the average incidence is affected only slightly by the inclusion of those returns.

Fig. 1 shows the incidence of skin disease in the various classes of ship irrespective of station. The general rise in incidence with increase in temperature is shown, although there is some variation of incidence between classes.

Further grouping of these results yields the curve, included in Fig. 2, which shows the general trend of the incidence of skin disease in relation to climatic temperature. Since the numbers on the attending list were determined weekly, the increase at the higher temperatures could be due to more men requiring medical attention, to a greater need for repeated attendances, or to both these causes.

Injuries.-A similarly detailed examination of the incidence of injuries was made. When for the different stations and classes of ship the incidence of injuries was plotted against climatic temperature no consistent relation with temperature was found, but there appeared to be a tendency for the incidence to increase in the hottest climates. The result of grouping the available returns from all ships except maintenance and depot ships is included in Fig. 2.

All Causes.-Fig. 2, which summarizes the returns from all ships other than maintenance and repair ships on all stations, shows the percentage on the attending list from all causes, and also the percentage due to the five separate disease groups in relation to upper deck temperature. The figure represents the general trend of minor sickness in H.M. ships, although in some classes, e.g., cruisers and frigates, and on some stations, e.g., the Persian Gulf and South Africa, the incidence at any temperature is likely to be higher than that indicated by the curve. 


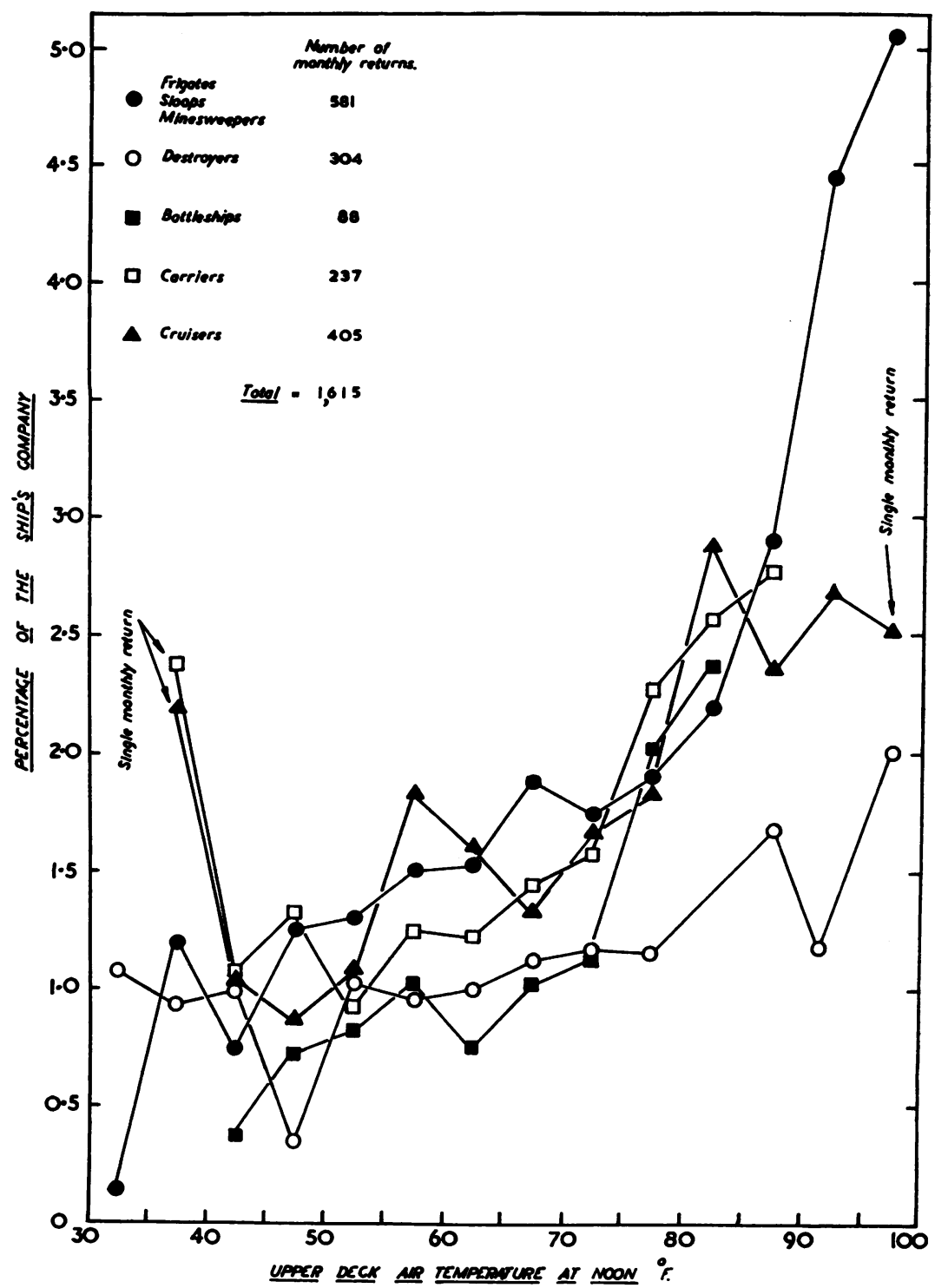

Fig. 1.-The percentage of a ship's company on the attending list with skin disease given as the average value for each class of ship, irrespective of the station on which they served, and the upper deck air temperature at noon.

There is a steady increase in minor sickness as the temperature rises. The increase is most noticeable in respect of skin disease and to a less extent in " all other diseases ", while with injuries the rise is only slight. With skin disease and with total sickness a pronounced increase occurs when the climatic temperature exceeds $80^{\circ} \mathrm{F}$, and when $90^{\circ} \mathrm{F}$. is exceeded the increase is very striking, although it is to be noted that the number of observations at temperatures above $90^{\circ} \mathrm{F}$. is small. Dysenteries normally account for but a small number of men on the attending list $(0.1 \%)$, but the proportion increased to about $0.3 \%$ in tropical weather. In cold weather upper respiratory diseases tend to increase, and a slight increase in the other disease groups, with the exception of dysenteries, is seen in very cold weather.

The composition of the total attending list at 


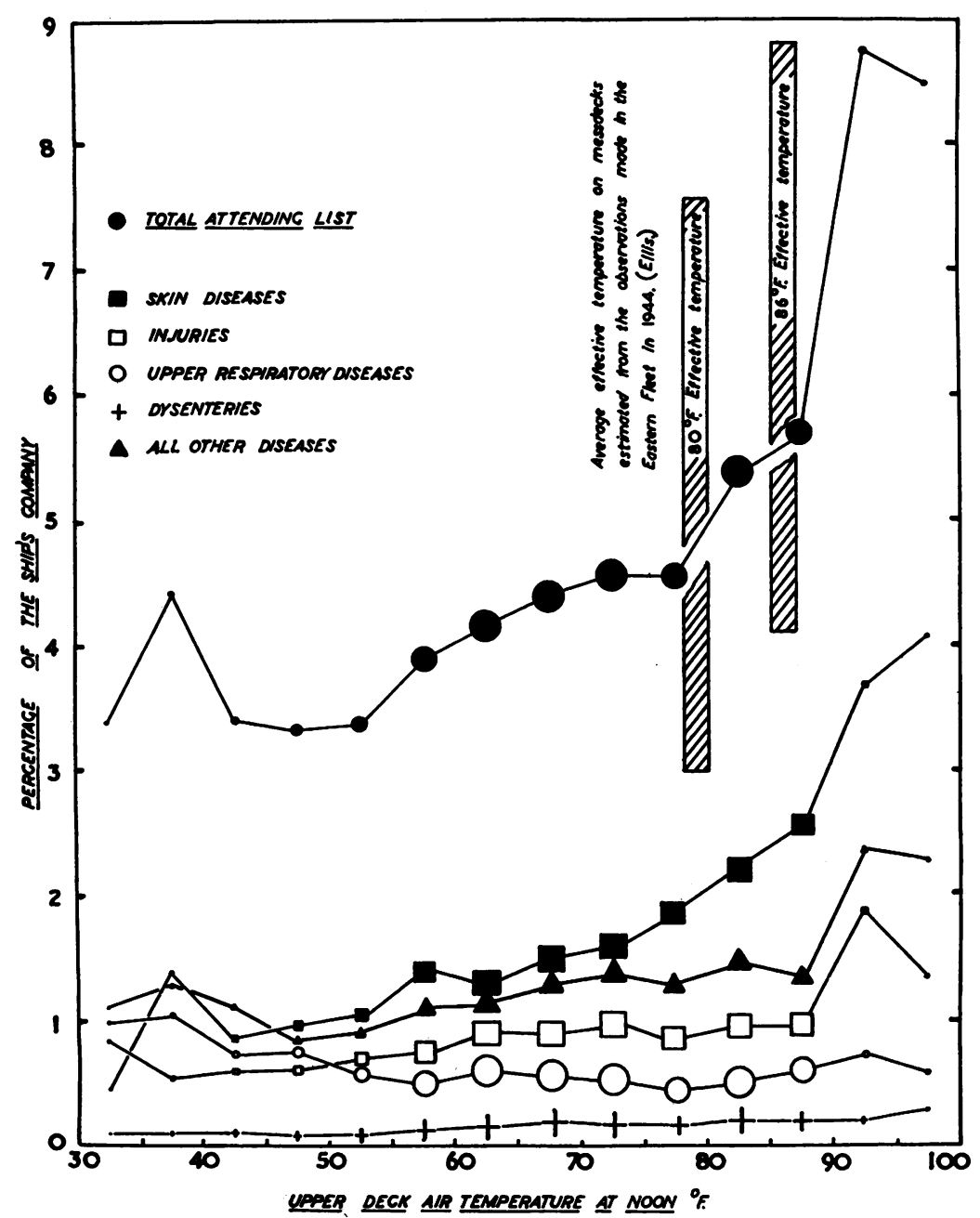

Fig. 2.-The percentage of a ship's company on the attending list given as the average value for all ships (except maintenance and repair ships) on all stations, and the upper deck air temperature at noon.

(The area of each point plotted in the diagram is proportional to the number of monthly returns from which the average was calculated.)

given ranges of upper deck temperature is given in Table 1. By far the most important group is skin diseases, which account for $30 \%$ of the attending list even in temperate waters, and for nearly half of it in very hot climates. In very cold weather upper respiratory diseases account for $23 \%$ of the total attending list, whereas the proportion is reduced to only $7 \%$ in very hot weather. Dysenteries, although tending to increase in number in hot weather, account for a very small proportion of the total attending list, injuries account for nearly one-fifth of the total, and all other diseases for rather less than one-third.
Effect of Air-conditioning on Incidence of Sickness on Attending List in Sloops.-In attempting to assess the effect of air-conditioning on the incidence of sickness it is preferable to consider individual ships and to compare directly the incidence of sickness before and after the installation of airconditioning equipment under the same climatic conditions on the same station. H.M.S. Wildgoose was air-conditioned in April, 1952, and H.M.S. Flamingo in October, 1949, and the returns received from these sloops permit direct comparisons to be made for periods when the ships served in the Persian Gulf. Sickness returns were also received 
TABLE 1

PROPORTION OF MEN ATTENDING THE SICK BAY ATTRIBUTABLE TO VARIOUS DISEASE GROUPS

\begin{tabular}{|c|c|c|c|c|c|c|}
\hline \multirow{2}{*}{$\begin{array}{l}\text { Upper Deck Air } \\
\text { Temperature } \\
\text { at Noon }\left({ }^{\circ} \mathbf{F} \text {.) }\right.\end{array}$} & \multirow{2}{*}{$\begin{array}{c}\% \\
\text { Attending } \\
\text { Sick Bay }\end{array}$} & \multicolumn{5}{|c|}{ Proportion ( $\%$ ) of Total No. Attending Sick Bay } \\
\hline & & Dysenteries & $\begin{array}{c}\text { Upper } \\
\text { Respiratory } \\
\text { Disease }\end{array}$ & Injuries & $\begin{array}{c}\text { All Other } \\
\text { Diseases }\end{array}$ & $\begin{array}{c}\text { Skin } \\
\text { Disease }\end{array}$ \\
\hline $\begin{array}{l}30-39 \\
40-49 \\
50-59 \\
60-69 \\
70-79 \\
80-89 \\
90-99\end{array}$ & $\begin{array}{l}4 \cdot 13 \\
3 \cdot 31 \\
3 \cdot 64 \\
4 \cdot 23 \\
4 \cdot 52 \\
5 \cdot 45 \\
8 \cdot 64\end{array}$ & $\begin{array}{r}2 \cdot 3 \\
2 \cdot 2 \\
2 \cdot 8 \\
3 \cdot 3 \\
3 \cdot 8 \\
3 \cdot 7 \\
2.9\end{array}$ & $\begin{array}{r}22.9 \\
22.3 \\
14.6 \\
13.6 \\
10 \cdot 4 \\
10 \cdot 0 \\
7.0\end{array}$ & $\begin{array}{l}15.3 \\
18.6 \\
19.8 \\
20.9 \\
19 \cdot 4 \\
17.2 \\
19 \cdot 4\end{array}$ & $\begin{array}{l}31 \cdot 9 \\
28 \cdot 8 \\
28 \cdot 7 \\
29 \cdot 1 \\
29 \cdot 0 \\
25 \cdot 8 \\
27 \cdot 1\end{array}$ & $\begin{array}{l}27 \cdot 6 \\
28 \cdot 1 \\
34 \cdot 1 \\
33 \cdot 1 \\
37 \cdot 4 \\
43 \cdot 3 \\
43 \cdot 6\end{array}$ \\
\hline
\end{tabular}

TABLE 2

COMPARISON OF PERCENTAGE OF SHIP'S COMPANY ON ATTENDING LIST BEFORE AND AFTER AIR-CONDITIONING IN SLOOPS

\begin{tabular}{|c|c|c|c|c|c|c|c|c|c|c|}
\hline \multirow{2}{*}{$\begin{array}{c}\text { Ship } \\
\text { and } \\
\text { Station }\end{array}$} & \multirow{2}{*}{$\begin{array}{c}\text { No. } \\
\text { Monthly } \\
\text { Returns }\end{array}$} & \multicolumn{2}{|c|}{$\begin{array}{c}\text { Average } \\
\text { Climatic } \\
\text { Temperature }\end{array}$} & \multirow{2}{*}{$\begin{array}{l}\text { Before or After } \\
\text { Installation of } \\
\text { Air-conditioning }\end{array}$} & \multicolumn{5}{|c|}{ Percentage of Ship's Company on Attending List with } & \multirow[b]{2}{*}{ Total } \\
\hline & & $\begin{array}{l}\text { Wet- } \\
\text { bulb } \\
\left({ }^{\circ} \mathbf{F} .\right)\end{array}$ & $\begin{array}{l}\text { Dry- } \\
\text { bulb } \\
\left({ }^{\circ} \mathrm{F} .\right)\end{array}$ & & $\begin{array}{c}\text { Upper } \\
\text { Respiratory } \\
\text { Disease }\end{array}$ & Dysenteries & $\begin{array}{c}\text { Skin } \\
\text { Disease }\end{array}$ & Injuries & $\begin{array}{l}\text { All Other } \\
\text { Diseases }\end{array}$ & \\
\hline $\begin{array}{l}\text { "Wildgoose" } \\
\text { Persian Gulf } \\
\text { "Flamingo" } \\
\text { Persian Gulf } \\
\text { "Wildgoose" } \\
\text { East Indies }\end{array}$ & $\begin{array}{l}6 \\
5 \\
5 \\
6 \\
1 \\
1\end{array}$ & $\begin{array}{l}83 \cdot 2 \\
84 \cdot 6 \\
81 \cdot 2 \\
80 \cdot 7 \\
83 \cdot 0 \\
83 \cdot 0\end{array}$ & $\begin{array}{l}92 \cdot 5 \\
93 \cdot 6 \\
94 \cdot 0 \\
91 \cdot 3 \\
89 \cdot 0 \\
88 \cdot 0\end{array}$ & $\begin{array}{l}\text { Before } \\
\text { After } \\
\text { Before } \\
\text { After } \\
\text { Before } \\
\text { After }\end{array}$ & $\begin{array}{l}0.73 \\
0.31 \\
0.97 \\
0.59 \\
- \\
-\end{array}$ & $\begin{array}{l}0 . \overline{08} \\
0.65 \\
0.02 \\
0.20 \\
0.05\end{array}$ & $\begin{array}{l}7 \cdot 43 \\
4 \cdot 20 \\
4 \cdot 75 \\
3 \cdot 06 \\
3 \cdot 27 \\
1 \cdot 53\end{array}$ & $\begin{array}{l}2 \cdot 16 \\
0 \cdot 25 \\
2 \cdot 82 \\
2 \cdot 27 \\
2.09 \\
0.90\end{array}$ & $\begin{array}{l}0.74 \\
0.64 \\
3.08 \\
2.62 \\
0.46 \\
0.63\end{array}$ & $\begin{array}{r}11.06 \\
5.48 \\
12.27 \\
8.56 \\
6.02 \\
3 \cdot 11\end{array}$ \\
\hline Both sloops & 12 & $82 \cdot 4$ & $92 \cdot 8$ & Before & 0.77 & 0.29 & $5 \cdot 97$ & $2 \cdot 43$ & 1.69 & $11 \cdot 14$ \\
\hline Both stations & 12 & $82 \cdot 5$ & 92.0 & After & 0.42 & 0.05 & $3 \cdot 41$ & $1 \cdot 31$ & $1 \cdot 63$ & $6 \cdot 82$ \\
\hline
\end{tabular}

from H.M.S. Wildgoose while she served on the East Indies Station, but only single monthly returns are available for comparison.

The comparisons made in Table 2 leave little room for doubt about the beneficial results of airconditioning when ships serve on hot stations. When the figures for both sloops are pooled it appears that, with average climatic conditions that were virtually identical, the incidence of skin diseases and of injuries were respectively 43 and $46 \%$ less with air-conditioning than without it, while the total attending list was reduced by $39 \%$.

\section{Discussion}

Incidence of Sickness and Standards of Environmental Warmth.-During the last war the high air temperatures and humidities in H.M. ships serving in tropical waters caused some concern, and the Royal Naval Personnel Research Committee was invited to define standards of environmental warmth which were compatible with the health and efficiency of the men. The Committee selected the effective temperature scale as the basis for its recommendations, and provisionally suggested that an effective temperature of $80^{\circ} \mathrm{F}$. was the upper desirable limit, and that $86^{\circ} \mathrm{F}$. was the highest effective temperature that could be accepted. From the standpoint of the men's efficiency the results of much research carried out since that time have generally supported this recommendation. Nevertheless, little information has been available to show whether health is impaired when these levels of warmth are exceeded for any length of time.

Our sickness returns record the temperature on the upper deck, but, by using the results obtained by earlier observers, it is possible to deduce from the upper deck temperatures the effective temperatures on the mess decks where the men live. A comprehensive survey of the thermal conditions in ships of the Eastern Fleet (Ellis, 1945) showed that on the average, in ships in the tropics, the internal air temperature was $8^{\circ} \mathrm{F}$. above the outside air temperature, the wet-bulb depression was about $9^{\circ} \mathrm{F}$., and the air speed about $90 \mathrm{ft}$. per min. Using these average values it can be computed that the general relation between the effective temperature on mess decks and the air temperature on the upper deck was that shown by the line in Fig. 3, in which the individual points represent the average values for various ships.

Of particular interest in this discussion are effective temperatures between $80^{\circ} \mathrm{F}$. and $86^{\circ} \mathrm{F}$. According to Fig. 3 these effective temperatures would be reached on mess decks with external air temperatures of about $78^{\circ} \mathrm{F}$. and $85^{\circ} \mathrm{F}$. respectively. These two temperatures have been indicated in Fig. 2.

The observations in the Eastern Fleet were made 


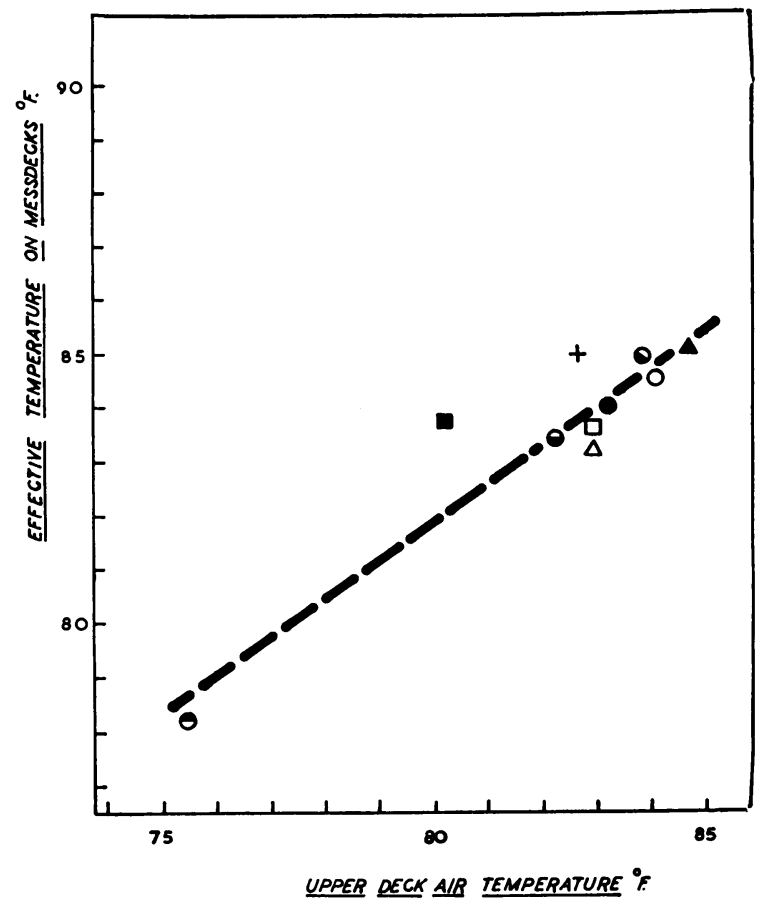

FIG. 3.-Estimate of the average effective temperature on mess decks generally for given upper deck air temperatures derived from 1,132 observations made in the eastern fleet in 1944.

(The plotted points are the averages of the observed values in eight ships. Three of the points represent measurements in the same ship on different occasions.)

during the war when ships were blacked out, whereas our returns relate to peace-time conditions. With a given upper deck temperature the temperature within a ship is therefore likely to be somewhat lower than in a similar ship during war. Yet even if the internal effective temperatures of $80^{\circ}$ and $86^{\circ} \mathrm{F}$. are associated with external air temperatures of, say, $80^{\circ}$ and $87^{\circ} \mathrm{F}$., the general conclusion is unaltered. Effective temperatures exceeding $80^{\circ} \mathrm{F}$. are highly undesirable.

Effect of Air-conditioning on Minor Sickness in Sloops.-The direct comparisons which have been made between the incidence of sickness in individual sloops in the Persian Gulf before and after airconditioning have shown clearly that with similar external conditions sickness was reduced considerably when the living spaces were air-conditioned. However, those comparisons give no indication of either the range of climatic conditions experienced in the Gulf during the course of a year, or of the incidence of sickness, and the effect of air-conditioning on it, at the different seasons. Hence they do not indicate fully the severity of living conditions in the Persian Gulf or the amelioration that results from air-conditioning. This information can be obtained by combining the figures relating to the two sloops (Table 3).

Table 3 shows the average climatic conditions observed at noon for each month of the year. It also shows for two-monthly periods the incidence of minor sickness before and after the air-conditioning of the living spaces. The high percentage of the ships' companies who during the hottest months were compelled to go to the sick bay for treatment for skin diseases when there was no air-conditioning reflects the severity of the conditions that prevailed. After air-conditioning had been installed the number of men who required treatment for skin diseases was greatly reduced, and it is reasonable to suppose that the much larger percentage of the men who had earlier suffered from prickly heat, but not badly enough to warrant going to the sick bay, must also have been much reduced as a result of air-conditioning.

Ventilation Standards and Incidence of Minor Sickness.-In view of the relation between minor

TABLE 3

AVERAGE MONTHLY CLIMATIC CONDITIONS OBSERVED IN PERSIAN GULF AND INCIDENCE OF MINOR SICKNESS FOR TWO-MONTHLY PERIODS IN SLOOPS WITH AND WITHOUT AIR-CONDITIONED MESS DECKS

\begin{tabular}{|c|c|c|c|c|c|c|c|}
\hline \multirow{3}{*}{ Month } & \multicolumn{3}{|c|}{$\begin{array}{c}\text { Average Conditions on Upper Deck } \\
\text { at Noon }\end{array}$} & \multicolumn{4}{|c|}{$\begin{array}{l}\% \text { Ship's Company on Attending List with and } \\
\text { without Air-conditioning }\end{array}$} \\
\hline & \multirow{2}{*}{$\begin{array}{l}\text { Dry-bulb } \\
\text { Temperature } \\
\left({ }^{\circ} \mathbf{F} .\right)\end{array}$} & \multirow{2}{*}{$\begin{array}{l}\text { Wet-bulb } \\
\text { Temperature } \\
\text { ( }{ }^{\circ} \mathbf{F} \text {.) }\end{array}$} & \multirow{2}{*}{$\begin{array}{l}\text { Relative } \\
\text { Humidity } \\
(\%)\end{array}$} & \multicolumn{2}{|c|}{ For Skin Diseases } & \multicolumn{2}{|c|}{ For All Causes } \\
\hline & & & & Without & With & Without & With \\
\hline $\begin{array}{l}\text { January } \\
\text { February } \\
\text { March } \\
\text { April } \\
\text { May } \\
\text { June } \\
\text { July } \\
\text { August } \\
\text { September } \\
\text { October } \\
\text { November } \\
\text { December }\end{array}$ & $\begin{array}{l}64 \\
68 \\
73 \\
80 \\
90 \\
94 \\
95 \\
96 \\
93 \\
89 \\
80 \\
70\end{array}$ & $\begin{array}{l}60 \\
63 \\
68 \\
74 \\
80 \\
82 \\
84 \\
83 \\
82 \\
79 \\
71 \\
64\end{array}$ & $\left.\begin{array}{l}80 \\
76 \\
78 \\
76 \\
65 \\
60 \\
64 \\
58 \\
63 \\
65 \\
65 \\
73\end{array}\right\}$ & $\begin{array}{l}1.81 \\
3.68 \\
5.45 \\
6.91 \\
6.60 \\
5.91\end{array}$ & $\begin{array}{l}1 \cdot 16 \\
2 \cdot 26 \\
4 \cdot 31 \\
3 \cdot 79 \\
4 \cdot 72 \\
1 \cdot 45\end{array}$ & $\begin{array}{r}5.66 \\
7 \cdot 18 \\
11 \cdot 57 \\
12 \cdot 04 \\
11 \cdot 07 \\
9.49\end{array}$ & $\begin{array}{l}5 \cdot 59 \\
5 \cdot 50 \\
7 \cdot 43 \\
6 \cdot 18 \\
9 \cdot 35 \\
6 \cdot 34\end{array}$ \\
\hline
\end{tabular}


sickness and climatic conditions and of the apparent effects of air-conditioning, it is of interest to consider whether minor sickness is likely to be reduced appreciably by improved standards of ventilation without the use of mechanical refrigeration. For ships that are not air-conditioned the naval constructor designs the ventilation equipment to cope with an external air temperature of $88^{\circ} \mathrm{F}$.

On some stations, e.g., Malaya, East Indies, and West Indies, even if ventilation lavish enough to keep the inside of the ship at virtually the same temperature as the outside air could be provided, effective temperatures in excess of $80^{\circ} \mathrm{F}$. would occur very commonly. At such effective temperatures there is an increased incidence of minor sickness, so that merely to increase the rate of ventilation would not give satisfactory results.

If minor sickness is to be reduced appreciably when ships serve on foreign stations it seems that air-conditioning of the living spaces, and of the working spaces where possible, will be needed. An impression of the reduction in minor sickness which might be expected to result from the air-conditioning of living spaces can be gained from inspection of Fig. 2. It may be argued that the numbers on the attending list would be lowered only by perhaps $2 \%$ of the ship's company, and that this is but a small proportion. Yet such an argument can be misleading, for besides those who attend the sick bay many men suffer from skin diseases in hot weather who are not driven to seek attention.

For every man attending the sick bay from this cause many more will probably be very uncomfortable with prickly heat. Hence a statement that $5 \%$ of the ship's company were on the attending list with skin disease gives an inadequate notion of the discomfort that was being experienced. If the $5 \%$ could be reduced to, say, $2 \frac{1}{2} \%$, far more than $2 \frac{1}{2} \%$ of the ship's company would be likely to gain considerable relief, and all would undoubtedly be far more comfortable.

\section{Summary}

Increased minor sickness during hot weather is seen on all stations and in all classes of ship which it has been possible to examine. When the climatic temperature at noon was about $60^{\circ} \mathrm{F} .3 \%$ of the ship's company were on the attending list. This proportion increased to $5 \%$ at $80^{\circ} \mathrm{F}$., and to about $9 \%$ when the temperature was above $90^{\circ} \mathrm{F}$. Except in the Persian Gulf air temperatures above $90^{\circ} \mathrm{F}$. were rare.

In the Persian Gulf the effect of air-conditioning sloops was striking. The attending list figures decreased from about $11 \%$ to about $7 \%$ of the ships' companies, while the incidence of skin disease was reduced by almost one half.

It is estimated that the effective temperature on mess decks will reach $80^{\circ} \mathrm{F}$. when the external temperature is about $80^{\circ} \mathrm{F}$, and the increase of minor sickness at external temperatures above $80^{\circ} \mathrm{F}$. supports an earlier opinion that an effective temperature higher than $80^{\circ} \mathrm{F}$. in ships is undesirable.

On most foreign stations climatic temperatures so often exceed $80^{\circ} \mathrm{F}$. that ventilation alone cannot be relied upon to keep the thermal conditions in ships down to recommended standards. This can be done only by air-conditioning.

The encouragement, help and advice given so readily on many occasions by Dr. T. Bedford and Dr. J. A. Fraser Roberts are very gratefully acknowledged.

\section{REFERENCES}

Ellis, F. P. (1945). First Report of the Habitability Mission to the Eastern Fleet, 1944. R.N.P. 45/202.

- Smith, F. E., and Underwood, C. R. (1952). The Effect of Upper Deck Temperature on the Health of Men in Ships of the Royal Navy. R.N.P. 52/720.

Roberts, J. A. Fraser (1948). Brit. J. soc. Med., 2, 55. 